\title{
EJ antibody antisynthetase syndrome
}

\author{
Andrew Robert Benck (1) , Augustine Manadan
}

Department of Rheumatology, Rush University Medical Center, Chicago, Illinois, USA

\section{Correspondence to}

Dr Andrew Robert Benck; andrew_r_benck@rush.edu

Accepted 22 February 2022

\section{DESCRIPTION}

A woman in her 50 s presented with several months of dyspnoea, joint pain and skin changes. She denied muscle weakness or dysphagia. Physical exam revealed hyperkeratosis and cracking at multiple fingertips (figure 1). Muscle strength was normal. CT of the chest revealed honeycombing and ground glass opacities in her bilateral lower lung lobes (figure 2). Laboratory testing revealed creatine kinase of $277 \mathrm{U} / \mathrm{L}(0-163 \mathrm{U} / \mathrm{L})$, aldolase of $19.7 \mathrm{U} / \mathrm{L}(<8.1 \mathrm{U} / \mathrm{L})$ and positive anti-EJ antibody greater than 100 SI $(<11$ SI). She was diagnosed with EJ antibody antisynthetase syndrome based on skin, lung and laboratory findings. She was started on prednisone $60 \mathrm{mg}$ by mouth daily and mycophenolate mofetil $500 \mathrm{mg}$ by mouth two times per day. After 1 month of treatment, her dyspnoea had stabilised and her mechanic's hands resolved.

Antisynthetase syndrome is characterised by the presence of an antiaminoacyl tRNA synthetase antibody (in this case, anti-EJ antibody) with one or more of the following clinical features: Raynaud's phenomenon, arthritis, mechanic's hands or hiker's feet, interstitial lung disease, fever and myositis. ${ }^{1}$ Interstitial lung disease is a prominent internal organ manifestation of the antisynthetase syndrome. ${ }^{23}$ Mechanic's hands is a cutaneous manifestation consisting of hyperkeratosis and cracking of the hands and fingertips. Hiker's feet is the same phenomenon occurring on the skin of the feet and tips of the toes. ${ }^{4}$ These skin findings should raise clinical suspicion for antisynthetase syndrome and prompt an investigation of antiaminoacyl tRNA synthetase antibodies as well as a thorough history to determine if other manifestations of the disease

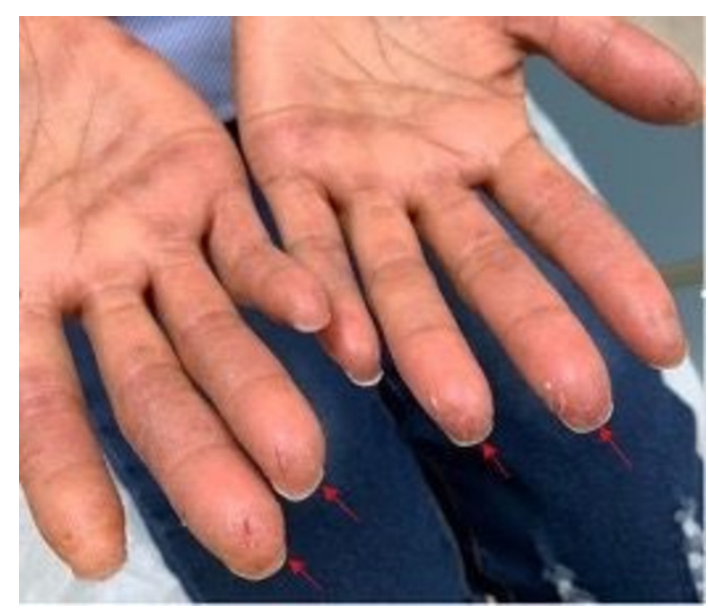

Figure 1 The patient's hands with cracking at the distal fingertips and cracking of the skin on the lateral and medial sides of the patient's fingers characteristic of mechanic's hands.

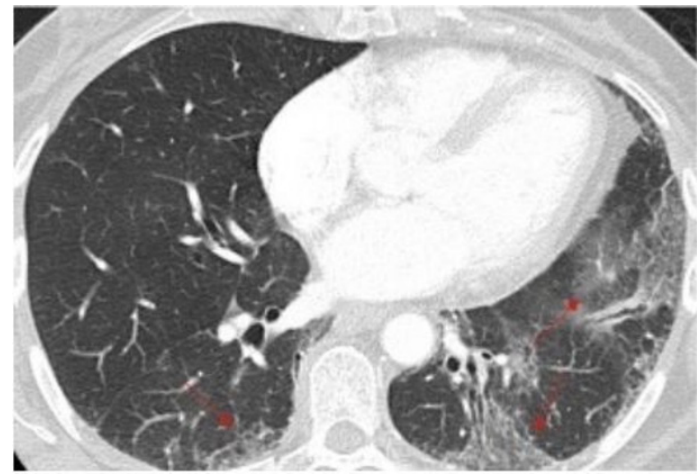

Figure 2 The patient's CT scan of the chest showing interstitial lung disease.

are present. The Connor's criteria and the Solomon's criteria are both useful diagnostic tools that clinicians can use in cases where antisynthetase syndrome is suspected. ${ }^{23}$ The presence of an antiaminoacyl tRNA synthetase antibody is required for diagnosis in both of these criteria.

\section{Learning points}

The presence of an antiaminoacyl tRNA synthetase antibody and one or more of the following clinical features should raise suspicion for antisynthetase syndrome: Raynaud's phenomenon, arthritis, mechanic's hands or hiker's feet, interstitial lung disease, fever and myositis.

- Mechanic's hands and hiker's feet should raise suspicion for antisynthetase syndrome.

- Interstitial lung disease is a prominent feature of antisynthetase syndrome.

- The Connor's criteria and the Solomon's criteria are useful tools for aiding in the diagnosis of antisynthetase syndrome.

Contributors I, ARB, assume the role of a guarantor. I along with AM examined and treated the patient presented in this manuscript. We reviewed the literature regarding the patient's condition and co-authored this manuscript.

Funding The authors have not declared a specific grant for this research from any funding agency in the public, commercial or not-for-profit sectors.

Competing interests None declared.

Patient consent for publication Consent obtained directly from patient(s).

Provenance and peer review Not commissioned; externally peer reviewed.

Case reports provide a valuable learning resource for the scientific community and can indicate areas of interest for future research.

They should not be used in isolation to guide treatment choices or public health policy. 


\section{Images in...}

\section{ORCID iD}

Andrew Robert Benck http://orcid.org/0000-0002-9533-055X

\section{REFERENCES}

1 Witt LJ, Curran JJ, Strek ME. The diagnosis and treatment of antisynthetase syndrome. Clin Pulm Med 2016;23:218-26.
2 Connors GR, Christopher-Stine L, Oddis CV, et al. Interstitial lung disease associated with the idiopathic inflammatory myopathies: what progress has been made in the past 35 years? Chest 2010;138:1464-74.

3 Solomon J, Swigris JJ, Brown KK. Myositis-related interstitial lung disease and antisynthetase syndrome. J Bras Pneumol 2011;37:100-9.

4 Katzap E, Barilla-LaBarca M-L, Marder G. Antisynthetase syndrome. Curr Rheumatol Rep 2011;13:175-81.

Copyright 2022 BMJ Publishing Group. All rights reserved. For permission to reuse any of this content visit

https://www.bmj.com/company/products-services/rights-and-licensing/permissions/

BMJ Case Report Fellows may re-use this article for personal use and teaching without any further permission.

Become a Fellow of BMJ Case Reports today and you can:

Submit as many cases as you like

- Enjoy fast sympathetic peer review and rapid publication of accepted articles

Access all the published articles

Re-use any of the published material for personal use and teaching without further permission

\section{Customer Service}

If you have any further queries about your subscription, please contact our customer services team on +44 (0) 2071111105 or via email at support@bmj.com.

Visit casereports.bmj.com for more articles like this and to become a Fellow 